\title{
Effects of Auditing Standards on Auditors Performance
}

\author{
Akinleye, G.T. (Ph.D) \\ Department of Accounting, Ekiti State University, Ado - Ekiti, Ekiti State \\ Olaoye, F.O. (Ph.D) \\ Department of Accounting, Ekiti State University, Ado - Ekiti, Ekiti State \\ Talabi, Amos O. \\ Department of Accountancy, Federal Polytechnic, Ile Oluji, Ondo State
}

\begin{abstract}
The objective of the research work is to examine whether application of auditing standards do enhance the quality of external auditor's performance. The research population for this work comprises of all external auditors in Ondo and Ekiti States. The primary source of data collection was employed and the stratified random sampling method was used to select the required sample size. The research instrument used for data collection was questionnaire and hundred (100) copies of questionnaire were administered and Eighty Six (86) were returned, representing $86 \%$. The 4-point Likert scale was logically employed to assign number to the measure of the degree of intensity of the relationships among the variables and the ordinary least squares (OLS) was used. The study revealed that there was a positive relationship between the auditing standards and auditor's performance and that auditor's performance often depends on their competency and ability to comply with required auditing standards. It is therefore recommended that the audit report should be expanded beyond complying with all standards by including a statement about the auditors' evaluation of the internal control mechanism and there should be need for more interpretations, clarifications and improvements in both International Auditing Standards (IASs) and the Nigerian Auditing Standards so as to enable auditors to improve more on their service deliveries
\end{abstract}

Keywords: Accounting Standard, Auditing Standard, External Auditors and Auditor's performance

DOI: $10.7176 / \mathrm{EJBM} / 12-21-05$

Publication date:July $31^{\text {st }} 2020$

\section{Introduction}

The auditing profession is awash in standards. Standards dictate how audit firms should structure their practice; how to hire, train, and reward their professional staff; what services to offer and clients to accept; how to conduct engagements; and how, and to whom, they are obligated to report (Knechel, Niemi and Zemi, 2013). Various professional and regulatory bodies have established ethical standards, independence standards, quality control standards, and audit performance and reporting standards. Whether issued by the American Institute of Certified Public Accountants (AICPA), the Public Company Accounting Oversight Board (PCAOB), the International Auditing and Assurance Standards Board (IAASB), or various national bodies like Institute of Chartered Accountants of Nigeria (ICAN), all standards have the effect of dictating, coordinating, and/or constraining professional auditors' activities and behavior (Igbinosun, 2011).

Standards are the model that should be used to judge an auditor's performance level. Auditing standards are important to the user of accounting reports and data such as banks, host community, shareholders, government, creditors etc. The standards explain the responsibility and independence of the auditor from the point of view of management and shareholders (Molid, 2010). International standards have been formulated to harmonize auditing practices between different nations and are to be applied where there are no local standards (European Commission, 2010). In Nigeria, the International Standards on Auditing (ISA) are mandatory for the companies quoted on the Nigeria Stock Exchange (NSE) where Nigerian Auditing Standards do not exist. But due to the peculiarity of the Nigerian environment on July, 2006, nine (9) Nigerian Standards on Auditing (NSA) were issued. These claimed priority over the ISAs in the Nigeria context. The objective of the audit of financial statements is to enable the auditor to express an opinion on whether the financial statements were prepared, in all material respects, in accordance with an identified financial reporting framework (IFAC, 2010)

We generally presume that all of these standards improve the quality of financial reporting Hermanson, Shrawer and Shrawer (2010). While many will take this perspective as an article of faith, it is still worthwhile to ask: Do auditing standards matter? The purpose of this study is to provide some insights into the effects of Auditing Standards on Auditor's performance based on an interpretation of existing theoretical and empirical research in auditing. It has been asserted that many Nigerian auditors are not complying with the general auditing standards, field work standards and reporting standards and that there is a need for guidelines for applying the broad concept of these requirements to Nigerian circumstances (Ohiokha and Akhalueh, 2013).

Some researchers such as Hay and Knechel (2010), Molid (2011), and Francis (2011) were able to establish 
the impact of auditing standards on auditor's performance but failed to verify the effect of competency and the credibility of audit staff on audit performance. Also, Causholli and Knechel(2012) and Ohiokha and Akhalumeh (2013) confirmed that the auditing standards, compliance, accounting standards except competence provide the required framework that ensures audit performance. All these researchers made little or no attempt to investigate into the in-depth causal link that might exist among auditing standards, accounting standards, compliance and auditor's competency. Against this backdrop, the paper therefore articulates and intends to examine the influence auditing standards on auditors' performance. The main objective of this research is to examine the effects of Auditing Standards on Auditor's performance.

\section{Conceptual Issues}

\section{Auditing Standards}

Auditing standards state that firms have the responsibility to implement a system of quality control, broadly defined as a process to provide the firm with reasonable assurance that its personnel comply with applicable professional standards and the firm's own standards of quality. International Standards on Quality Control (ISQC) are more definitive on the issue of review as a quality control mechanism, saying that all firms "should establish policies and procedures, requiring, for appropriate engagements, an engagement quality control review that provides an objective evaluation of the significant judgments made by the engagement team and conclusions reached in formulating the report'" (IFAC, 2009).

\section{Accounting Standards}

Apart from the Local standards, Nigeria also uses International Financial Reporting Accounting to formulate domestic accounting standards as an attempt to emulate financial requirements in more developed capital markets. According to Igbinosun (2011) the survey done by the International Finance Corporation in 1995 suggests that Nigeria has an adequate quality of domestic accounting standards. Even when adequate financial accounting standards exist, they further observe, political, economic and socio- cultural factors make the enforcement a problem

The above assertion is corroborated by Ohiokha \& Akhalumeh (2013) who observed that the problem of corruption in Nigeria and its influence on accounting and auditing practices can be traced to the various changes in its socio-political and economic environment.

\section{Empirical Review}

Standard setting is just one form of external control exerted over audit professionals. This essay started with a quote from Francis, (2011), which suggested that a primary benefit of standards is that they provide a benchmark against which an audit can be evaluated. This view is consistent with the arguments that standards can provide a partial constraint on strategic (or negligent) behaviour by an auditor. In the current financial reporting environment, setting new standards is an automatic reaction to most perceived problems with audit quality. Problems need solutions, and new standards are a straightforward and visible reaction to a problem. However, it is not clear that standardization is fully compatible with the exercise of professional judgment and skepticism needed to conduct high quality audits in a very complex and rapidly evolving business environment.

Elder, Beasley, and Arens (2010) argue that in some nations, the International Auditing Guidelines (IAG) have been adopted without any change(s), in many others, they have been adopted with such modifications as are considered appropriate in the context of the domestic conditions. The ISA acknowledges that difference in financial reporting frameworks between countries result in comparative financial information being presented differently in each framework (Gill \& Cossert 2008). Generally Accepted Auditing Practices (GAAP) which is the overall guidelines for auditing establishes the framework within which an auditor decides the necessary action to take in preparing for the examination of financial statements, in performing the examination and in writing the report. Hermanson, Shrawer and Shrawer (2010) view auditing standards as a measure used in determining the ability of the auditor in the performance of the procedures and the objectives to be attained by the use of the procedures undertakes.

Auditing standards set minimum standards of technical proficiency in auditing. These standards are applicable to each financial report audit made by an independent auditor regardless of the size of the entity, the form of business organization, the type of industry or whether the entity is for profit or not for profit. Shareholders and other users should be informed in the scope section of the audit report that the audit has been conducted in accordance with specified auditing standards (Ohiokha and Akhalumeh 2013).

Causholli, and Knechel (2012) state that to raise the confidence of financial statement users about the standard of auditors' performance, they need to be aware that auditors' compliance with several standards (ethical, quality control and technical) is being monitored stringently. "It is therefore important that reports on the monitoring process and its outcomes - including the sanctions imposed on those found not to complying fully with the standards - be placed in the public domain." Contemplating on the 'reasonableness gap', Causholli, and Knechel 
(2012) proclaim that society in general needs to be educated about the audit function and what auditors can and cannot reasonably be expected to achieve. They suggest that auditors could, for example, stimulate discussion about the auditor's role and responsibilities within a section of society that extends beyond members of bodies such as the institute of directors, shareholders' and business associations, and the accounting profession. An alternative is to seek opportunities to educate influential journalists about the audit function and work of auditors. From that, journalists may report adverse events affecting auditors in a more informed and less sensational manner (Elder et al., 2010).

Hay and Knechel (2010) in his work title 'The effects of advertising and solicitation on audit fees' stressed that all auditors should possess adequate professional proficiency to perform their tasks. The SAIs should recruit personnel with suitable qualifications, adopt policies and procedures to develop and train SAI employees to performance their tasks effectively, prepare written guidance concerning the conduct of audits, support the skills and experience available with the SAI and review the internal procedures. The ability to recruit the right staff is a decisive factor in performance auditing. Each staff member is a unique investment. A performance auditor must be well educated, and in general it is required that the auditor should have a university degree and experience in investigative/evaluation work. Personal qualities are also of considerable importance (analytical ability, creativity, receptiveness, social skills, integrity, judgment, endurance, good oral and writing skills etc.) (Causholli et al., 2012).

\section{Methodology}

For the purpose of this study, a descriptive survey method was adopted in which the hypothesis stated was tested. The stratified sampling method was employed. The population consists of all the external auditors in Ondo and Ekiti States, Nigeria, and then the required sample size was disproportionally selected from each stratum after the population was divided into different strata. Primary source of the data was used, using the simple random sampling approach, 100 questionnaires were distributed out of which 86 were returned. Forty nine (49) questionnaires were returned in Ondo state while thirty seven (37) were also retuned in Ekiti State.

\section{Model Specification}

The model used in this study was adopted from existing works such as Ohiokha, et al (2013), Causholli, and Knechel (2012) and postulated by this paper is given as:

AUDPERT $=$ F [ACCSTND, AUDSTND, COMPET, and COMPLI]

i.e AUDPERT $=b_{0}+b_{1}$ AUDSTND $+b_{2}$ ACCSTND + $b_{3}$ COMPET + $b_{4}$ COMPLI --------------2

where: dependent variable is auditors' performance (AUDPERT).

Independent variable is Auditing Standards (AUDSTND), while the Control variables are three i.e Accounting Standards (ACCSTND) Competence (COMPET) and Compliance (COMPLI)

Dependent and Independent variables are all measure based on the responses of the respondents to questions asked in the questionnaire that relates to performance of auditors, accounting standards, auditing standards, competence and compliance by auditors to the standards regulatory the auditing profession.

\section{Estimation Technique}

The method of estimation technique employed for the study was the ordinary least squares (OLS). This was used because apart from being simply. It minimizes the square error between the data or variables used in the work.

\section{Result Analysis and Presentation}

The analysis was done based on the data collected through respondents then processes using Ordinary Least Square (OLS) technique.

Table 1: Regression Results of Auditing Standards on Auditor's performance

\begin{tabular}{|c|c|c|c|c|c|c|c|}
\hline Model & Sum of Squares & R Square & Adjusted R Square & Std. Error of the Estimate & $\mathrm{df}$ & Mean Square & $\mathrm{F}$ \\
\hline & 2.433 & .070 & .059 & .699 & 3 & .811 & 1.59 \\
\hline
\end{tabular}

Source: Field work (2017)

From the Table 1 above, it is observed that the co-efficient of determination (R square) stood at 0.070 which means that $7 \%$ of the systematic variations in the auditor performance level are explained by the variations in the explanatory variables in the model. Although, it is very low goodness of fit implying that most of the variations in auditor's performance is determined by the unexplained variables that are not captured in the model but can attributed to the error term. The F-statistic of 1.59 as a measure of the overall goodness of fit at $5 \%$ significance level suggests that the linear function specified in the model might not be the case. 
Table 2: The results of the Correlations among the Variables

\begin{tabular}{|l|l|l|l|l|l|}
\hline & Audperf & Audsnd & Compet & Acctsnd & Compli \\
\hline Audperf & 1 & .169 & .553 & .215 & .261 \\
\hline Audsnd & .169 & 1 & .102 & $.264^{*}$ & .373 \\
\hline Compet & .553 & .102 & 1 & $.280^{*}$ & .104 \\
\hline Acctsnd & .215 & $.264^{*}$ & $.280^{*}$ & 1 & .178 \\
\hline Compli & .261 & .373 & .104 & .178 & 1 \\
\hline
\end{tabular}

Source: Field work (2017)

The correlation result in table 2 above reveals that the independent variables show positive relationship with dependent variable (auditor's performance). Categorically, auditing standards(AUDSND) and auditor performance were found to be positively correlated with a correlation coefficient of 0.169 , this is very low, it means that a weak association exist between them. Result also shows that Competency (COMPET) and performance are correlated positively at 0.517 . This shows a high relationship, thus, it implies that competency is required and imperative factor that improves auditor's performance. It also noted that Compliance (COMPLI) and Auditor' Performance (AUDPERF) are correlated positively at 0.263 this is weak, though the direction of association is positive.

\section{Discussions of Findings}

Having examined the coefficients of the control variables, it reveals that the Auditing standard (AUDSND) is positive. This suggests that Auditor's performance is subject to the understanding of auditing standards and other acceptable standards which provide the required framework that ensures audit performance. However, the effect is statistically insignificant at 5\% level. This could imply that the application of auditing standards, though imperative but, might not be a sufficient and appropriate factor in ensuring auditor's performance. By implication, adherence to such standards and proper regulations to ensure compliance will be critical in achieving significant improvements in audit performance.

The result also reveals that the variables Accounting Standards (ACCTSND) is positive. This suggests that the accounting standards provide the required framework that improves auditor's performance. It shows that adherence to such standards and proper regulation will be critical in achieving significant improvement in auditor's performance.

The variable Compliance (COMPLI) is positive. This indicates that compliance with standards is also important to enhance auditor's performance. This result upholds the study of Causholli, and Knechel (2012) who suggested that to rise the confidence of financial statement users about the standard of auditors' performance, they need to be aware that auditors' compliance with several standards (ethical, quality control and technical) is being monitored stringently. This was equally in line with the findings of Ohiokha, and Akhalumeh (2013) that the auditing standards, compliance, accounting standards except competence provide the required framework that ensures audit performance.

Finally, the variable Competency is positive which implies that the effect of auditor's competence level on audit performance is imperative. This negates the finding of (Ohiokha, \& Akhalumeh (2013) that asserted no significant relationship between Competence (COMPET) and auditor's performance. This work therefore upholds the view of Hay (2010) who suggested that all auditors should possess adequate professional proficiency to perform their tasks. He stressed further that ability to recruit the right staff is a decisive factor in performance auditing. Each staff member is a unique investment. The study reveals that control variables (such as accounting standards, compliance and competency) lend to exhibit positive association into auditor performance, which means independent auditors in Nigeria in performing their audit engagement do comply with the auditing and accounting standards as required by laws.

\section{Conclusion and Recommendations}

The study evaluates auditing standards and auditors performance. It was observed that the role of auditing has changed from the simple requirement that all resources have been duly accounted for, and that all uses were in accordance with the directives of the noble man in modern society an audit is viewed as providing assurances as to the performance of management in public companies whose investors may be national or international.

It is therefore suggested that the activities of professionals should be investigated by independent regulatory institutions in order to know whether they comply with all required standards and IASs, should reconsider the external auditor's responsibility for detecting and disclosing the major or all fraud in the audit report. This will bridge the gap between the perceptions of auditor's performance and other stakeholders. Based on the findings above, the following are suggested:

1. The audit report should be expanded beyond complying with all standards by including a statement about the auditors' evaluation of the internal control system and the results of reviewing the entity's ability to continue in the future. Expectation of the audit report to explain in more details what the auditor does and 
does not and the degree of assurance provided by an audit to shareholders and other users of the audit report will add to the quality of auditor's performance

2. All auditors should possess adequate professional proficiency to perform their tasks. The Audit Firm should recruit personnel with suitable qualifications, adopt policies and procedures to develop and train audit team to performance their tasks effectively, prepare written guidance concerning the conduct of audits.

3. There should be need for more interpretations, clarifications and improvements in both International Auditing Standards (IASs) and the Nigerian Auditing Standards so as to enable auditors to improve more on their service deliveries.

4. The Nigerian accounting professional bodies should ensure that they enforce and maintain their acclaimed duty to see that their members exercise due diligence and act in a morally and ethically upright manner and in the best interests of their clients and of the Nigerian public as a whole.

\section{References}

Causholli, M., and W. R. Knechel. (2012): An examination of the credence attributes of an audit, Accounting Horizons 26 (4): 631-656.

Causholli, M., W. R. Knechel, H. Lin, and D. E. M. Sappington (2013). Competitive Procurement of Auditing Services with Limited Information. European Accounting Review (forthcoming).

Cullinan, C. P., C. E. Earley, and P. B. Roush (2013). Multiple Auditing Standards and Standard Setting: Implications for Practice and Education. Current Issues in Auditing 7 (1): C1 C10.

Eilifsen, A., W.F. Messier Jr, S.M. Glover, and D.W. Prawitt (2010), Auditing and Assurance Services, Second International Edition, McGraw-Hill Education, Maidenhead, Berkshire

Elder, R.J., M.S Beasley, and A.A. Arens (2010), Auditing and Assurance Services: an Integrated Approach: Global Edition, $13^{\text {th }}$ ed., Prentice-Hall, Englewood Cliffs, $N J$

Francis, J. R. (2011). A framework for Understanding and Researching Audit Quality. Auditing: A Journal of Practice \& Theory 30 (2): 125-152.

Gill, G. \& Cossert, G. (2008). Modern Auditing in Australia (4th ed.) Australia, John Wiley and Sons.

Hay, D., and W. R. Knechel (2010). The Effects of Advertising and Solicitation on Audit Fees. Journal of Accounting and Public Policy 29 (1): 60-81.

Hay, D., W. R. Knechel, And N. Wong (2010). Audit Fees: A Meta-Analysis of the Effect Of Supply and Demand Attributes. Contemporary Accounting Research 23 (1): 141-191.

Hermanson, R., Shrawer, R. \& Shrawer, J. (2010) Auditing Theory and Practice (3rd ed.)Boston US, Homewood Publishers.

Holm, C., and F. Thinggaard. (2010): Joint Audits: Benefit or Burden. Working paper, Aarbus Business School.

IAASB (2004), Project History: the Independent Auditor's Report on a Complete set of General Purpose Financial Statements - completed. http://www.ifac.or g/IAASB/P roject History.php? ProjID=0013

IASB (2005), Framework for the Preparation and Presentation of Financial Statements (Framework), in: International Financial Reporting Standards (IFRSs), United Kingdom: IASCF

IFAC (2010), Handbook of the Code of Ethics for Professional Accountants, http://web.i fac.org/publications/international-ethics-standards-board-for-accountants/code-of-ethics

Igbinosun, F.E. (2011). An Evaluation of the Auditing Standards and their Application to the Auditing of Registered Companies in Nigeria. An M.Sc Project Presented to the Department of Accounting University of Benin, Benin City.

Jean C. B., Donald R., Mary B., \& Gregory J. (2012). Risk Monitoring and Control in Audit Firms: A Research Synthesis, A Journal Of Practice \& Theory, Vol. 27, No. 1, pp.187-218.

Knechel, W. R., G. Krishnan, M. Pevzner, L. Shefcik, and U. Vellury (2013). Audit Quality Indicators: Insights from the Academic Literature. Auditing: A Journal of Practice \& Theory (forthcoming).

Knechel, W. R., P. Rouse, and C. Schelleman (2010). A Modified Audit Production Framework: Evaluating the Relative Efficiency of Audit Engagements. The Accounting Review 84 (5):1607-1638.

Molid, S. (2009). Analyzing Study. The International Auditing Standards. Journal of Administrative Science, 1; 123-145

Ohiokha, Friday Izien \& Akhalumeh, Paul Benign (2013). Auditing Standards and Auditor's Performance: The Nigerian Experience, European Journal of Accounting Auditing and Finance Research, Vol. 1, No.1, March 2013, pp.29-3

Willekens, M. A., and D. Simunic (2012). Precision in Auditing Standards: Effect on Auditor and Director Liability and the Supply and Demand for Audit Services. Accounting and Business Research 37(3): 217-232.

Ye, M., D. Simunic, and R. Winter (2009). The Economics of Setting Auditing Standards. Working paper, University of British Columbia. 